\title{
Influence of phosphate fertilization on the growth and nutrient status of micropropagated apple infected with endomycorrhizal fungi during the weaning stage
}

\author{
B Branzanti $1^{\star}$, V Gianinazzi-Pearson $2^{\star *}$, S Gianinazzi 2 \\ 1 Università di Bologna, DIPROVAL, Via Filippo Re 8, Bologna, Italy; \\ 2 INRA-CNRS, Laboratoire de Phytoparasitologie, SGAP, INRA, BV 1540, 21034 Dijon Cédex, France \\ (COST Meeting, 21-23 May 1992, Dijon, France)
}

\begin{abstract}
Summary - Microplants of 2 apple rootstocks (M9, M26) and one cultivar (Golden) were inoculated with VAM fungi during a very early weaning stage of acclimatization following micropropagation and supplied with nutrient solution at different $P$ concentrations. Phosphate fertilization containing a high level of $P(40 \mathrm{ppm})$ had no effect on the growth response of mycorrhizal apple plants. At the lower levels of 8 and $4 \mathrm{ppm}$ P mycorrhizal plants maintained the same growth rate as with $40 \mathrm{ppm} P$. Phosphate fertilization had no influence on endomycorrhizal infection. No difference was observed in the mineral contents of mycorrhizal and nonmycorrhizal plants, or between plants receiving different levels of $P$. At the lower fertilization rates of $P$, endomycorrhizal infection not only improved growth but also homogeneity of Golden and M26 plants.
\end{abstract}

\section{P supply / endomycorriza / micropropagated apple}

\begin{abstract}
Résumé - Influence de la fertilisation phosphatée sur la croissance et le statut nutritif de pommiers micropropagés infectés par des champignons endomycorhiziens pendant la période de sevrage. Des microplantes de 2 porte-greffes de pommier (M9, M26) et d'un cultivar (Golden) ont été inoculés avec des champignons VAM pendant une phase très précoce de l'acclimatation, après la micropropagation, et ont reçu des solutions nutritives comprenant des doses variables de $P$. La fertilisation phosphatée à un niveau élevé de $P(40 \mathrm{ppm})$ n'a pas eu d'effet sur la réponse de croissance de plantes de pommiers mycorhizées. A des niveaux plus faibles de 8 et $4 \mathrm{ppm}(P)$ les plantes mycorhizées ont la même vitesse de croissance que celles recevant 40 ppm de $P$. La fertilisation phosphatée n'a pas eu d'influence sur l'infection mycorhizienne. On n'a observé aucune différence entre la composition minérale des plantes mycorhizées et celle des plantes qui ne l'étaient pas, ni entre celles de plantes ayant reçu différentes doses de P. Aux bas niveaux de fertilisation phosphatée, linfection mycorhizienne a amélioré non seulement la croissance, mais aussi l'homogénéité de Golden et de M26.
\end{abstract}

fertilisation phosphatée / endomycorhize / pommier micropropagé

\section{INTRODUCTION}

Micropropagated fruit trees are strongly dependent on the presence of endomycorrhizal fungi for growth; the technique of in vitro propagation, where plants are grown in sterile media and then transplanted into artificial substrata lacking VA fungi, strongly reduces or does not allow the formation of mycorrhizae. Inoculation with VA fungi appears to play a key role in the survival and growth of micro- plants, as has been observed in grapevine (Schubert et al, 1987, 1988, 1990), apple and pear (Granger et al, 1983; Branzanti et al, 1989). Previous studies on grapevine (Ravolanirina et al, 1989b) have shown that post vitro inoculation during an early stage of acclimatization is more efficient for plant development than in vitro inoculation. Furthermore, potting mixes used in horticultural systems can affect the response of plants to mycorrhizal infection (Branzanti et al, 1991).

\footnotetext{
* Present address: Dipartimento di Biotecnologie Agrarie ed Ambientali, Universita degli Studi di Ancona, Via Breccie Bianche, 60737 Ancona, Italy

"* Correspondence and reprints
} 
The effect of endomycorrhization on fruit crops in different horticultural substrata (Branzanti et al, 1991) has shown that mixes containing soil and peat with either vermiculite or perlite give best results for the growth of inoculated plants. Addition of $P$ fertilizer to the soil can reduce or increase the growth of mycorrhizal plants depending on endophyte species (Schubert et al, 1990). In this study we have compared the effect of phosphate fertilization on the growth response and nutritional status induced by mycorrhizal inoculation in micropropagated apple plants.

\section{MATERIALS AND METHODS}

Microplants of 2 apple rootstocks (M9, M26) and 1 cultivar (Golden) were inoculated or not with endomycorrhizal fungi (Glomus fasciculatum, $G$ mosseae, $G$ intraradices) during a very early weaning stage of acclimatization following micropropagation, according to the technique described by Ravolanirina et al (1989a). After 2 wk, well-infected microplants were transplanted into $400 \mathrm{~g}$ pots containing a clay-loam soil-peat-gravel mix (2/1/1) and grown in a controlled temperature $\left(20-25{ }^{\circ} \mathrm{C}\right)$ greenhouse (April-July). Plants received weekly $20 \mathrm{ml}$ Long Ashton solution containing 1 of 3 different levels of phosphate (40, 8 and $4 \mathrm{ppm} \mathrm{P).} \mathrm{After} 12$ wk growth the plants were harvested and the height, stem diameter, fresh shoot and root mass were assessed. Shoot mineral contents ( $P$, $\mathrm{K}, \mathrm{Mg}, \mathrm{Zn}, \mathrm{Cu}, \mathrm{Fe}$ ) were analysed. $\mathrm{P}$ was determined colorimetrically by the phosphomolybdovanadate procedure after complete digestion in perchloric acid; $\mathrm{K}$, $\mathrm{Mg}, \mathrm{Zn}, \mathrm{Cu}$ and $\mathrm{Fe}$ were determined by atomic absorption spectrophotometry. Endomycorrhizal infection was estimated after staining the roots with trypan blue (Phillips and Hayman, 1970), as intensity (M\%) of infection, according to the method of Trouvelot et al (1986). In each experiment, pots were randomized and each of the treatments $(40,8$ and 4 ppm P) consisted of 6 replicate pots. All data were subjected to analysis of variance; significant differences between treatment means were separated by Newman-Keuls test.

\section{RESULTS}

At the end of the experimental period, all inoculated plants were mycorrhizal with fractional root colonization ranging from $37-49 \%$. Mycorrhizal infection was not particularly affected by phosphate fertilization, although root colonization was significantly higher in $\mathrm{M} 9$ plants receiving $4 \mathrm{ppm}$ than in those receiving $8 \mathrm{ppm} P$ (table I), while no significant difference was observed in Golden and M26 plants at the same fertilization rate.

Table I. Effect of 3 different levels of $P$ fertilization on growth and mycorrhizal infection of micropropagated apple 12 wk after inoculation.

\begin{tabular}{|c|c|c|c|c|c|c|c|c|}
\hline \multirow[t]{3}{*}{ Plant } & \multirow{3}{*}{$\begin{array}{l}\text { Level of } P \\
\quad(p p m)\end{array}$} & \multirow[t]{3}{*}{ Treatment } & \multirow{3}{*}{$\begin{array}{c}\text { Level of } \\
\text { infection } \\
M \%\end{array}$} & \multicolumn{5}{|c|}{ Plant growth } \\
\hline & & & & & & Fres & mass & \\
\hline & & & & $\begin{array}{l}\text { Height } \\
(\mathrm{cm})\end{array}$ & $\begin{array}{c}\text { Stem } \\
\text { diameter } \\
(\mathrm{cm})\end{array}$ & $\begin{array}{l}\text { Shoot } \\
(g)\end{array}$ & $\begin{array}{l}\text { Root } \\
(g)\end{array}$ & $R / S$ \\
\hline \multirow[t]{3}{*}{ M9 } & 40 & $\begin{array}{l}\text { G fasciculatum } \\
\text { noninoculated }\end{array}$ & $\begin{array}{c}43.96^{\mathrm{abc}} \\
-\end{array}$ & $\begin{array}{l}23.60^{\mathrm{a}} \\
23.80^{\mathrm{a}}\end{array}$ & $\begin{array}{l}0.39^{a} \\
0.38^{a}\end{array}$ & $\begin{array}{l}7.02^{\mathrm{a}} \\
6.53^{\mathrm{a}}\end{array}$ & $\begin{array}{l}3.74^{\mathrm{a}} \\
3.56^{\mathrm{a}}\end{array}$ & $\begin{array}{l}0.52^{b} \\
0.54^{b}\end{array}$ \\
\hline & 8 & $\begin{array}{l}\text { G fasciculatum } \\
\text { noninoculated }\end{array}$ & $\begin{array}{c}36.86^{\mathrm{a}} \\
-\end{array}$ & $\begin{array}{r}28.08^{\mathrm{a}} \\
5.00 \mathrm{~b}\end{array}$ & $\begin{array}{l}0.40^{\mathrm{a}} \\
0.29^{\mathrm{b}}\end{array}$ & $\begin{array}{l}7.93^{a} \\
1.06 b\end{array}$ & $\begin{array}{l}3.87^{\mathrm{a}} \\
1.16^{\mathrm{b}}\end{array}$ & $\begin{array}{l}0.48^{b} \\
1.07^{a}\end{array}$ \\
\hline & 4 & $\begin{array}{l}\text { G fasciculatum } \\
\text { noninoculated }\end{array}$ & $\begin{array}{c}48.60^{c} \\
-\end{array}$ & $\begin{array}{r}26.70^{\mathrm{a}} \\
0.85 \mathrm{~b}\end{array}$ & $\begin{array}{l}0.40^{\mathrm{a}} \\
0.31^{\mathrm{b}}\end{array}$ & $\begin{array}{l}7.79^{a} \\
2.47 b\end{array}$ & $\begin{array}{l}4.61^{\mathrm{a}} \\
2.14^{\mathrm{b}}\end{array}$ & $\begin{array}{l}0.59^{a b} \\
0.98^{a}\end{array}$ \\
\hline Golden & 8 & $\begin{array}{l}G \text { mosseae }+G \text { intraradices } \\
\text { noninoculated }\end{array}$ & $\begin{array}{c}46.32^{b c} \\
-\end{array}$ & $\begin{array}{l}34.33^{a} \\
15.66^{b}\end{array}$ & $\begin{array}{l}0.42^{\mathrm{a}} \\
0.29^{\mathrm{b}}\end{array}$ & $\begin{array}{l}9.5^{\mathrm{ab}} \\
2.7^{\mathrm{b}}\end{array}$ & $\begin{array}{r}10.69^{\mathrm{a}} \\
3.71^{\mathrm{b}}\end{array}$ & $\begin{array}{l}1.13^{\mathrm{a}} \\
1.45^{\mathrm{a}}\end{array}$ \\
\hline M26 & 4 & $\begin{array}{l}G \text { mossae }+G \text { intraradices } \\
\text { noninoculated }\end{array}$ & $\begin{array}{c}38.94^{\mathrm{ab}} \\
-\end{array}$ & $\begin{array}{r}38.1^{\mathrm{a}} \\
7.2^{\mathrm{b}}\end{array}$ & $\begin{array}{l}0.51^{\mathrm{a}} \\
0.27^{\mathrm{b}}\end{array}$ & $\begin{array}{r}10.73^{a} \\
1.26^{b}\end{array}$ & $\begin{array}{r}11.57^{a} \\
1.00^{b}\end{array}$ & $\begin{array}{l}0.83^{a b} \\
0.75^{b}\end{array}$ \\
\hline
\end{tabular}


In M9 plants, growth was not affected by VAM inoculation at the highest level of fertilization; no difference was observed in terms of development between inoculated and uninoculated M9 plants during the entire duration of the experiment (table I). At the lower levels of phosphate fertilization, M9 mycorrhizal plants were significantly taller, had significantly larger stem diameter, greater fresh mass and reduced root-shoot ratio as compared to uninoculated controls; nonmycorrhizal plants did not grow or grew poorly. A similar pattern was observed in Golden and M26 plants receiving phosphate fertilization rates of 8 and $4 \mathrm{ppm}$ respectively. These showed significantly increased shoot height, stem diameter and root fresh weight, while nonmycorrhizal plants grew 2-5-fold less. The growth difference between mycorrhizal and nonmycorrhizal plants was first observed visually 4 wk after inoculation and lasted up to the end of the experiment.

Endomycorrhizal infection affected the homogeneity of inoculated plants. As reported in table II, the values of variation coefficients for mycorrhizal plants were generally lower than those in nonmycorrhizal plants at the intermediate and lowest levels of $P$ ( 8 and $4 \mathrm{ppm}$ ) for Golden, $M 26$, and M9. At the highest phosphate fertilization, mycorrhizal inoculation had no influence on the homogeneity of M9 plants (table II).

Phosphate fertilization did not affect the mineral content of mycorrhizal and nonmycorrhizal plants (table III). No difference was observed in leaf concentrations of $\mathrm{P}, \mathrm{K}, \mathrm{Mg}, \mathrm{Fe}, \mathrm{Zn}$, or $\mathrm{Cu}$ between plants inoculated with mycorrhizal fungi or receiving different rates of $P$.
Table II. Variation coefficients (\%) of mycorrhizal (M) and nonmycorrhizal ( $\mathrm{nM}$ ) apple plants at different levels of $P$.

\begin{tabular}{|c|c|c|c|c|c|}
\hline \multirow{2}{*}{$\begin{array}{l}\text { Plant } \\
\text { M9 }\end{array}$} & \multicolumn{2}{|c|}{ Treatment } & Height & $\begin{array}{c}\text { Shoot } \\
\text { fresh mass }\end{array}$ & $\begin{array}{c}\text { Root } \\
\text { fresh mass }\end{array}$ \\
\hline & $40 \mathrm{ppm}$ & $\begin{array}{l}\mathrm{M} \\
\mathrm{nM}\end{array}$ & $\begin{array}{c}16 \\
16\end{array}$ & $\begin{array}{l}20 \\
17\end{array}$ & $\begin{array}{l}30 \\
16\end{array}$ \\
\hline & $8 \mathrm{ppm}$ & $\begin{array}{l}M \\
n M\end{array}$ & $\begin{array}{l}10 \\
20\end{array}$ & $\begin{array}{l}13 \\
20\end{array}$ & $\begin{array}{l}26 \\
31\end{array}$ \\
\hline & $4 \mathrm{ppm}$ & $\begin{array}{l}\mathrm{M} \\
\mathrm{nM}\end{array}$ & $\begin{array}{l}21 \\
13\end{array}$ & $\begin{array}{l}20 \\
18\end{array}$ & $\begin{array}{l}16 \\
13\end{array}$ \\
\hline
\end{tabular}

Golden

$8 \mathrm{ppm} \mid \begin{array}{lrrr}\mathrm{M} & 9 & 14 & 3 \\ \mathrm{nM} & 45 & 41 & 46\end{array}$

M26

$4 \mathrm{ppm} \mid \begin{array}{lrrr}\mathrm{M} & 7 & 9 & 20 \\ \mathrm{nM} & 46 & 38 & 60\end{array}$

\section{DISCUSSION AND CONCLUSION}

These results confirm previous observations that phosphate fertilization at high levels has no effect on the growth of mycorrhizal micropropagated apple but eliminates the mycorrhizal responses by enhancing the growth of uninoculated plants (Branzanti et al, 1989). In this experiment nonmycorrhizal plants supplied with a nutrient solution containing $40 \mathrm{ppm} P$ grew as well as in-

Table III. Leaf mineral content of mycorrhizal and nonmycorrhizal apple plants at different levels of soluble P.

\begin{tabular}{|c|c|c|c|c|c|c|c|c|}
\hline Plant & $\begin{array}{l}\text { Plevel } \\
(p p m)\end{array}$ & Treatment & $\begin{array}{c}P \\
(\%)\end{array}$ & $\begin{array}{c}K \\
(\%)\end{array}$ & $\begin{array}{l}M g \\
(\%)\end{array}$ & $\begin{array}{c}F e \\
(\mu g / g)\end{array}$ & $\begin{array}{c}Z n \\
(\mu g / g)\end{array}$ & $\begin{array}{c}C u \\
(\mu g / g)\end{array}$ \\
\hline M9 & 40 & $\begin{array}{l}\text { G fasciculatum } \\
\text { noninoculated }\end{array}$ & $\begin{array}{l}0.18 \\
0.18\end{array}$ & $\begin{array}{l}1.34 \\
1.39\end{array}$ & $\begin{array}{l}0.23 \\
0.24\end{array}$ & $\begin{array}{l}524 \\
535\end{array}$ & $\begin{array}{l}51 \\
49\end{array}$ & $\begin{array}{l}6.2 \\
6.1\end{array}$ \\
\hline & 8 & $\begin{array}{l}\text { G fasciculatum } \\
\text { nonoculated }\end{array}$ & $\begin{array}{l}0.17 \\
0.17\end{array}$ & $\begin{array}{l}1.36 \\
1.36\end{array}$ & $\begin{array}{l}0.22 \\
0.22\end{array}$ & $\begin{array}{l}568 \\
531\end{array}$ & $\begin{array}{l}47 \\
53\end{array}$ & $\begin{array}{l}6.4 \\
6.4\end{array}$ \\
\hline & 4 & $\begin{array}{l}G \text { fasciculatum } \\
\text { noninoculated }\end{array}$ & $\begin{array}{l}0.17 \\
0.17\end{array}$ & $\begin{array}{l}1.35 \\
1.34\end{array}$ & $\begin{array}{l}0.23 \\
0.27\end{array}$ & $\begin{array}{l}528 \\
519\end{array}$ & $\begin{array}{l}49 \\
52\end{array}$ & $\begin{array}{l}6.2 \\
6.8\end{array}$ \\
\hline Golden & 8 & $\begin{array}{l}G \text { mosseae }+G \text { intraradices } \\
\text { noninoculated }\end{array}$ & $\begin{array}{l}0.17 \\
0.17\end{array}$ & $\begin{array}{l}1.45 \\
1.39\end{array}$ & $\begin{array}{l}0.22 \\
0.23\end{array}$ & $\begin{array}{l}590 \\
560\end{array}$ & $\begin{array}{l}47 \\
41\end{array}$ & $\begin{array}{l}6.0 \\
6.6\end{array}$ \\
\hline M26 & 4 & $\begin{array}{l}G \text { mosseae }+G \text { intraradices } \\
\text { noninoculated }\end{array}$ & $\begin{array}{l}0.17 \\
0.17\end{array}$ & $\begin{array}{l}1.09 \\
1.27\end{array}$ & $\begin{array}{l}0.23 \\
0.20\end{array}$ & $\begin{array}{l}508 \\
516\end{array}$ & $\begin{array}{l}50 \\
38\end{array}$ & $\begin{array}{l}6.3 \\
6.4\end{array}$ \\
\hline
\end{tabular}


oculated plants. Mycorrhizal plants grew equally well at the lower levels of 8 and $4 \mathrm{ppm} P$ and maintained the same production as with $40 \mathrm{ppm}$ $P$, whilst nonmycorrhizal plants grew very poorly (2-5-fold less).

Endomycorrhizal infection was also unaffected by phosphate fertilization. This does not agree with results obtained by other authors who report that phosphate applications markedly influence endophyte development in the host plant (Mosse, 1973; Menge et al, 1978). Planchette et al (1983a) observed that increasing $P$ fertilizer levels reduced endomycorrhizal infection in apple trees, but this value was not always maximum for the lowest $P$ level. Endomycorrhizal root colonization is affected by the host-fungus combination; the results reported here confirm these observations. At the lower rates of $P$ fertilization, statistically significant different levels of root infection were observed depending on the host plant-endophyte combination. Several workers have reported a higher tissue concentration of $\mathrm{P}$ and other nutrients in mycorrhizal plants (Hayman and Mosse, 1971; Ross, 1971; Powell and Daniel, 1978; Lambert et al, 1979). Planchette et al (1983b) observed that enhancement of mineral content in inoculated apple plants occurs only at the lowest $P$ level. In our experiment mycorrhizal inoculation and phosphate fertilization, on the contrary, had no effect on leaf mineral contents. This suggests that neither growth stimulation of mycorrhizal plants nor that of plants receiving different levels of phosphate may be explained by higher mineral concentrations in foliar tissues. Interestingly, endomycorrhizal inoculation did have a positive influence on the homogeneity of micropropagated apple plants at lower levels of $P$ fertilization.

In conclusion, these results clearly show that early endomycorrhizal inoculation ensures maximum growth of apple microplants after outplanting, even under conditions of phosphate stress, and has positive effects on the uniformity of plants produced in vitro. This biotechnology therefore appears to be of potential interest in guaranteeing an optimum production of micropropagated fruit trees during the nursery stage.

\section{REFERENCES}

Branzanti B, Ravolanirina F, Gianinazzi S (1989) Endomicorrizazione di fruttiferi micropropagati. In: Symp Colture In Vitro e Micropropagazione in Ortoflorofrutticoltura. Cesena, 2 June 1989, 77-82
Branzanti B, Gianinazzi-Pearson V, Gianinazzi S, Predieri S, Baraldi $R$ (1991) Influence of artificial substrata on mycorrhization of micropropagated fruittrees in a horticultural system. In: Mycorrhizas in Ecosystems (Alexander IJ, Fitter AH, Lewis $\mathrm{DH}$, Read DJ, eds) CAB International, Oxon (UK) 333339

Granger RL, Planchette C, Fortin JA (1983) Effect of a vesicular-arbuscular (VA) endomycorrhizal fungus (Glomus epigaeum) on the growth and leaf mineral content of two apple clones propagated in vitro. Can J Plant Sci 63, 551-555

Hayman DS, Mosse B (1971) Plant growth response to vesicular-arbuscular mycorrhiza. I. Growth of endogone-inoculated plants in phosphate-deficient soils. New Phytol 70, 19-27

Lambert DH, Baker DE, Cole H Jr (1979) The role of mycorrhizae in the interactions of phosphorus with zinc, copper and other elements. Soil Sci Soc Am J 43, 976-980

Menge JA, Steirle D, Bagyaraj DJ, Johnson ELV, Leonard RT (1978) Phosphorus concentration in plants responsible for inhibition of mycorrhizal infections. New Phytol 80, 575-578

Mosse B (1973) Advances in the study of vesiculararbuscular mycorrhiza. Ann Rev Phytopathol 11, 171-196

Phillips JM, Hayman DS (1970) Improved procedures for clearing roots and staining parasitic and vesicular-arbuscular mycorrhizal fungi for rapid assessment of infection. Trans Br Mycol Soc 55, 158-160

Planchette C, Furlan V, Fortin JA (1983a) Responses of endomycorrhizal plants grown in a calcined montmorillonite clay to different levels of soil phosphorus. I. Effect on growth and mycorrhizal development. Can J Bot 61, 1377-1383

Planchette C, Furlan V, Fortin JA (1983b) Responses of endomycorrhizal plants grown in a calcined montmorillonite clay to different levels of soluble phosphorus. II. Effect on nutrient uptake. Can J Bot $61,1385-1391$

Powell CLL, Daniel J (1978) Mycorrhizal fungi stimulate uptake of soluble and insoluble phosphate fertilizer from a phosphate-deficient soil. New Phytol $80,351-358$

Ravolanirina F, Blal B, Gianinazzi S, GianinazziPearson V (1989a) Mise au point d'une méthode rapide d'endomycorhization de vitroplants. Fruits 44 , 165-171

Ravolanirina F, Gianinazzi S, Trouvelot A, Carre M (1989b) Production of endomycorrhizal explants of micropropagated grapevine rootstocks. Agric Ecosystems Environ 29, 323-327

Ross JP (1971) Effect of phosphate fertilization on yield of mycorrhizal and nonmycorrhizal soybeans. Phytopathology 61, 1400-1403

Schubert A, Mazzitelli M, Gribaudo I (1987) Effect of inoculation with vesicular-arbuscular mycorrhizal fungi on micropropagated Vitis berlandieri $\mathrm{x}$ Vitis ri- 
paria Kober 5 BB. Proc Symp Florizel 87 Arlon (Belgium), 144-153

Schubert A, Eynard I (1988) Growth and root colonization of grapevines inoculated with different mycorrhizal endophytes. Hortsci 23, 302-303

Schubert A, Mazzitelli M, Ariusso O, Eynard I (1990) Effects of vesicular-arbuscular mycorrhizal fungi on micropropagated grapevines: influence of endo- phyte strain, $\mathrm{P}$ fertilization and growth medium. $V_{i}$ tis 29, 5-13

Trouvelot A, Kough JL, Gianinazzi Pearson V (1986) Mesure du taux de mycorhization VA d'un système radiculaire. Recherche de méthodes d'estimation ayant une signification fonctionnelle. In: Physiological and Genetical Aspects of Mycorrhizae (GianinazziPearson V, Gianinazzi S, eds) INRA, Paris, 217-221 